Misr J. Ag. Eng., 26(2): 624- 643

FARM MACHINERY AND POWER

\title{
BEST MANAGEMENT PRACTICES AFFECTING THE PERFORMANCE OF A TWIN DISC FERTILIZER SPREADER IN NEW RECLAIMED AREAS
}

\author{
Mohamed Ali Tawfik* ${ }^{*}$ and Islam M. M. Khater ${ }^{* *}$
}

\begin{abstract}
Soil, especially in reclaimed areas, need fertilizing application to rich it with all plants requirement of nutrient elements, but due to the consequent increase of commercial fertilizer prices and the desire to prevent the environmental contamination by the excessive application rates, the best management practices of fertilizer broadcasting machines become more important nowadays. Hence, the aim of this investigation was to evaluate and predict the performance of a twin-disc spreader using granular Ammonium Nitrate during fertilizing sugar beet through two main groups of experiments, the first was the preliminary experiment, to select the proper operating parameters. Without overlapping, The obtained results showed that the lower value of coefficient of variation $(C . V)$ and highest values of correlation $\left(R^{2}\right)$ were achieved at spinner speed $52.3 \mathrm{rad} / \mathrm{s}(500 \mathrm{rpm})$, backward blade angle of ${ }^{-15}$, spinner angle of zero degree and gate opening area of $18 \mathrm{~cm}^{2}$ using four C-shaped blade and spinner height of $50 \mathrm{~cm}$. While the second one was the field experiment which carried out according to the results of preliminary experiment by using the computer programmer of Curve Fit 1.37 (2001) which expressed the relationship between forward speed and the parameters affecting the performance of spreader such as; application rate, pattern uniformity, energy requirement, total yield and spreading cost to predict the performance of spreader. Also, the obtained data showed that the high degree of uniformity and correlation between operating factors were achieved at overlap percentage of $42.8 \%$ equals to effective swath width of $11 \mathrm{~m}$ which gave an acceptable pyramidal pattern.
\end{abstract}

*Lecturer of Agric. Eng .Dep., Fac. of Agric., Zagazig Univ., Egypt. **Researcher of Agric. Mech., Soil Conservation Dep., Desert Res., Centre, Egypt. 


\section{INTRODUCTION}

7 he main target of best management practices of fertilizer broadcasting machines is become nowadays more important economically due to the consequent increase of commercial fertilizers prices all over the world, because the fertilizer industry becomes more expensive, in addition, the efficient environmental practices by applying the optimum application rates that meet plant growth requirement without excessive addition, gave a good nutrient soil without contamination for both soil and environment. The broadcasting of commercial fertilizers on the soil surface by using the granular applicators is more popular representing in centrifugal spreaders (either single or double disc) because of their simplicity, high ground clearance, wide swath width and low price. Ahmed et al (1990) found that the suitable rotational speed of spinner for granular fertilizer is about $500 \mathrm{rpm}$ (spinner diameter $500 \mathrm{~mm}$ ) Morad (1990) showed that the uniformity of fertilizer distribution affected by spreader speed, blade pitch, spreader dip angle and fertilizer type. Hofstee (1993) mentioned that the uniformity of spread pattern of fertilizers is become more important for both economic and environmental reasons to ensure that fertilizers are not applied unnecessary. Kamel et. al (2002) found that backward pitched angle blade $\left(-10^{\circ}\right)$ with different rotational speeds of spinner improved the pattern distribution. Larry and Bandel (2002) reported that oval pattern is the best pattern for both the single or double disc fertilizer spreaders because the effective overlap with this pattern was about $60 \%$ of the theoretical width that was about $20 \%$ of the swath width must be overlapped, also the pyramid pattern was an acceptable pattern because the effective overlap was only $50 \%$ of the theoretical width. Hassan et. al (2005) showed that the high degree of uniformity can be achieved by using the spinner speed of $500 \mathrm{rpm}$, (spinner diameter $500 \mathrm{~mm}$ ) blade angle of ${ }^{+} 15^{\circ}$, spinner dip angle $0^{\circ}$, spinner height $50 \mathrm{~cm}$, straight $\mathrm{C}$-shape blade. The main objectives of the study were to (1).Evaluate some operating parameters affecting the performance of a twin-disc fertilizer spreader in new reclaimed areas, (2).Determine and modeling the optimum operating factors to predict and select the proper operating 
parameters, (3). Make the best management practices to supply information for improving the performance of spreader by investigating the relationship between forward speed, application rate, pattern uniformity, energy requirement, total yield and spreading cost.

\section{MATERIALS AND METHODS}

The experiments were carried out at a private farm in Eastern Qantara (Ismailia Governorate) during fertilizing sugar beet through two main experiments, the first experiment (preliminary experiment) was performed at stationary position of a twin disc fertilizer spreader to optimize and modeling some operating parameters and use the obtained results of the second one (field experiment) to evaluate and modeling the performance of the spreader with different forward speeds during fertilizing sugar beet. The field experiment was performed using Ammonium Nitrate (Amm.N.) on sandy loam soil, Table (1) shows some properties of soil profile and the physical properties of the used fertilizer were given in Table (2).

\section{A- MATERIALS:}

Table (1): Some properties of soil profile representing the experimental site.

\begin{tabular}{|c|c|c|c|c|}
\hline $\begin{array}{c}\text { Soil Depth } \\
(\mathbf{c m})\end{array}$ & $\begin{array}{c}\text { Clay } \\
(\boldsymbol{\%})\end{array}$ & $\begin{array}{c}\text { Silt } \\
(\boldsymbol{\%})\end{array}$ & $\begin{array}{c}\text { Sand } \\
(\boldsymbol{\%})\end{array}$ & Texture class. \\
\hline $0-15$ & 8.26 & 2.50 & 89.24 & Sandy Loam \\
$15-30$ & 16.1 & 29.94 & 53.96 & Sandy Loam \\
\hline
\end{tabular}

Table (2): The physical properties of fertilizer.

\begin{tabular}{|c|c|c|c|c|}
\hline $\begin{array}{c}\text { Fertilizer } \\
\text { Type }\end{array}$ & $\begin{array}{c}\text { Moisture } \\
\text { Content, } \\
\text { \% }\end{array}$ & $\begin{array}{c}\text { Bulk } \\
\text { Density } \\
\mathbf{k g} / \mathbf{m}^{3}\end{array}$ & $\begin{array}{c}\text { Angle of } \\
\text { repose } \\
\text { (degrees) }\end{array}$ & $\begin{array}{c}\text { Coefficient } \\
\text { of friction }\end{array}$ \\
\hline $\begin{array}{c}\text { Amm. } \\
\text { Nitrate }\end{array}$ & $11-13$ & 850 & 40 & 0.52 \\
\hline
\end{tabular}

The specifications of tractor and broadcasting machine used were illustrated in Tables (3), (4) and Fig. (1). 
Table (3): The used tractor.

\begin{tabular}{|c|c|}
\hline Type & Belaruss MTZ-80 \\
\hline Source & Russia \\
\hline Engine Type & 4 Stroke- Diesel \\
\hline Power & $66.2 \mathrm{~kW}$ \\
\hline P.T.O & $540-1000 \mathrm{rpm}$ \\
\hline Ground Clearance & $350 \mathrm{~mm}$ \\
\hline Mass & $3500 \mathrm{~kg}$ \\
\hline
\end{tabular}

Table (4): The overall specification of the broadcasting machine.

\begin{tabular}{|c|c|}
\hline Model & ÖNTAR \\
\hline Source & Turkey \\
\hline Type & Mounted twin disc \\
\hline Hopper capacity & 950 lit. \\
\hline No. of blades & 8 \\
\hline Spinner diameter & $500 \mathrm{~mm}$ \\
\hline $\begin{array}{c}\text { Theoretical spreading } \\
\text { width }\end{array}$ & $12-18 \mathrm{~m}$ \\
\hline
\end{tabular}
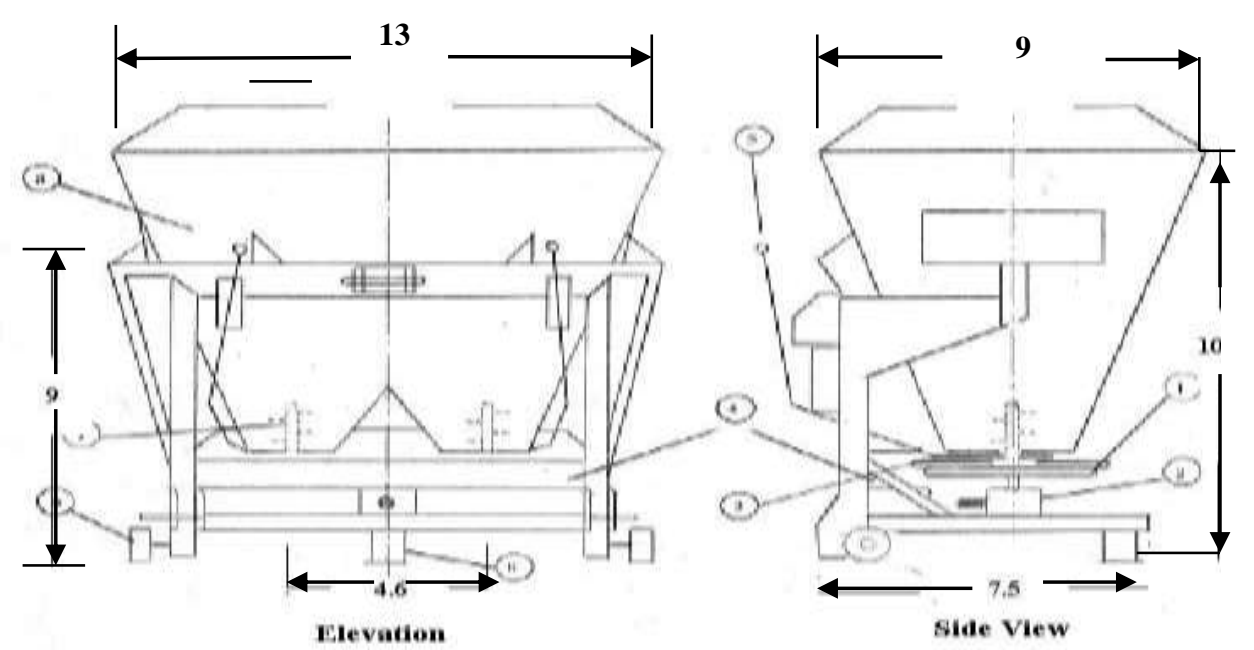

\begin{tabular}{|c|l|c|c|c|c|}
\hline No. & Part Name & $\begin{array}{c}\text { Material } \\
\text { Type }\end{array}$ & No & Part Name & $\begin{array}{c}\text { Material } \\
\text { Type }\end{array}$ \\
\hline 1 & Spinner & Steel sheet & 6 & Supporter & Iron \\
\hline 2 & Gear box & Iron & 7 & Agitator & Iron \\
\hline 3 & Sliding gate & Steel sheet & 8 & Hopper & Steel \\
\hline 4 & Deflector & Steel sheet & 9 & Wheels & Plastic \\
\hline 5 & lever & Steel & \multicolumn{2}{|c|}{ Scale 1: 50} & Dim. In cm. \\
\hline
\end{tabular}

Fig.(1): Elevation and side view of the spreader. 


\section{B- METHODS:}

\section{1-The preliminary experiment:}

The first experiment was carried out to optimize and modeling the factors affecting the uniformity of the spread pattern and chosen to be in the following magnitudes:

1- Four different values of spinner speeds $(31.4,41.86,52.3$ and 62.8 $\mathrm{rad} / \mathrm{s})$ were used corresponding to $(300,400,500$ and $600 \mathrm{rpm})$

2- Three different blade angles (radial, ${ }^{+} 15^{\circ}$ and ${ }^{-1} 15^{\circ}$ ) were used.

3- Three different values of spinner dip angle $\left(0,{ }^{+} 10\right.$ and $\left.{ }^{+} 20^{\circ}\right)$ were used.

4- Four different gate opening areas $\left(6,12,18\right.$ and $\left.24 \mathrm{~cm}^{2}\right)$ were tested.

The spreader has four blades C- straight in shape and spinner adjusted at $50 \mathrm{~cm}$ above the ground according to Sayedahmed (1989) and Hassan et. al (2005)

\section{2-The field experiment:}

The field experiment was carried out on the optimum parameters which were obtained from the preliminary one to evaluate and modeling the performance of the spreader with four different forward speeds of (2.5, 4.5, 6.0 and $8.0 \mathrm{~km} / \mathrm{h}$ ) for predicting some engineering parameters of the spreader during fertilizing sugar beet. The sugar beet was cultivated on 8 feddans, which were divided into 12 equal plots having dimensions of 40x $70 \mathrm{~m}$ and four treatments were investigated and replicated three times. In all experimental plots, seedbed preparation, planting method, irrigation and crop service operations were conducted according to the technical recommendations.

\section{C-MEASUREMENTS:}

\section{1-The preliminary experiment measurements ;}

\section{a-Distribution uniformity}

The distribution pattern uniformity was evaluated according to ASAE S 341.3 (2004) consists of collection trays with dimensions of $32 \times 22 \times 10$ $\mathrm{cm}$, measuring tape, a funnel, plastic bags, stop watch and electronic balance. Coefficient of variation (C.V), coefficient of uniformity (C.U) 
and pattern skewing (S) were calculated by weighting the collected materials in each tray after every treatment.

\section{1- Coefficient of variation (C.V.):}

The coefficient of variation was calculated according to ASAE S 341.3 (2004) as follows:

$$
\delta=\sqrt{\frac{\sum(\mathrm{Xi}-\mathrm{Xa})^{2}}{n-1}}
$$

Where: $\delta=$ standard deviation

$$
\begin{aligned}
& \mathrm{Xi}=\text { weight of material in each box } \\
& \mathrm{Xa}=\text { average weight of material of all boxes }=\mathrm{X}_{\mathrm{a}}=\frac{\sum \mathrm{xi}}{\mathrm{n}} \\
& \mathrm{n}=\text { number of boxes } \\
& \mathrm{C} . \mathrm{V}=\frac{\delta}{\mathrm{xa}} \times 100
\end{aligned}
$$

2-Coefficient of distribution uniformity (C.U) \% :

The distribution uniformity coefficient was determined by the equation of Ziauddin and Khan (2002) as follows :

$$
C . U=\left[1-\frac{\sum_{i=1}^{n}(X i-X a)^{2}}{n X a}\right] x 100
$$

\section{3-Pattern skewing (S):}

Pattern skewing was calculated by using the following equation

$$
\mathrm{S}=\frac{\mathrm{Lz} \%}{\mathrm{Rz} \%}
$$

where: $\mathrm{S}=$ Pattern skewing (\%) and $\mathrm{Lz}, \mathrm{Rz}=$ mass of fertilizer collected from both the left and right sides respectively.

\section{2-The field experiment measurements:}

The field experiments were performed when wind speed exceeds $2.22 \mathrm{~m} / \mathrm{s}$ at height of $1.5 \mathrm{~m}$ above ground and taking into consideration the following indicators: 


\section{a- Overlap percentage (\%):}

The ratio between the covering zone in subsequent pass at the edges of pattern to the theoretical spreading width.

\section{b- Effective field capacity $\left(\boldsymbol{F} . C_{\text {eff }}\right)$ :}

The effective field capacity is calculated using the following equation.

$$
F C_{\text {eff }}=\frac{S W E_{f}}{4.2} \quad(\mathrm{fed} / \mathrm{h})
$$

where: $\mathrm{S}=$ Travel speed, $\mathrm{km} / \mathrm{h}$

$\mathrm{W}=$ Effective swath width, $\mathrm{m}$

$\mathrm{E}_{\mathrm{f}}=$ Field efficiency, $(\%)$

$\mathrm{E}_{\mathrm{f}}=$ (Theo. time /Actual operating time $) \times 100$

c-Power requirement $(\mathrm{Pr})$ :

The engine power was estimated by the following formula of Hunt (1983):

$$
\operatorname{Pr}=\left[\mathrm{F} . \mathrm{C}(1 / 3600) P E . L C V .427 . \xi_{t h b} \cdot \xi_{m} \cdot 1 / 75.1 / 36\right](\mathrm{kW}) \ldots \ldots .
$$

where: $F . C=$ Fuel consumption, $($ lit/h)

P.E= Fuel density (for solar $0.85 \mathrm{~kg} / \mathrm{m}^{3}$ )

$\mathrm{LCV}=$ Calorific value of fuel $(11000 \mathrm{k} . \mathrm{cal} / \mathrm{kg})$

$\xi_{t h b} .=$ Thermal efficiency of engine (35\% for diesel engine)

$\xi_{m}=$ Mechanical efficiency of the engine (85\%)

The energy can be determined as follows:

Energy requirement $(\mathrm{kW} . \mathrm{h} / \mathrm{fed})=$ Required power $(\mathrm{kW}) /$ Effective field capacity (fed/h).. (6)

\section{d- Cost analysis:}

The spreading cost of spreading was calculated by the following equation:

spreading cost $($ L. E. /fed $)=$ Machine cost $($ L. E. /h)/ Effective field capacity $(\mathrm{fed} / \mathrm{h})$

Where machine hourly cost can be estimated by the following formula of Awady (1978)

$$
\mathrm{C}=\frac{\mathrm{P}}{\mathrm{h}}\left(\frac{1}{\mathrm{E}}+\frac{\mathrm{I}}{2}+\mathrm{T}+\mathrm{R}\right)+(0.9 \mathrm{~W} \cdot \mathrm{S} \cdot \mathrm{F})+\frac{\mathrm{M}}{144}
$$

Where C: Hourly cost, (L.E/h).

$$
\mathrm{P}=\text { Price of the machine, (L.E). }
$$


$\mathrm{h}=$ Yearly working hours.

$\mathrm{E}=$ Life expectancy of the machine, (year).

$\mathrm{I}=$ Interest rate, $(\%) /$ year.

$\mathrm{T}=$ Taxes, over heads ratio, $(\%)$.

$\mathrm{R}=$ Repair and Maintenance ratio, $(\%)$.

$\mathrm{W}=$ Power, $(\mathrm{kW})$.

$\mathrm{S}=$ specific fuel consumption, $(\mathrm{L} / \mathrm{kW} \cdot \mathrm{h})$.

$\mathrm{F}=$ Fuel price, (L.E).

$\mathrm{M}=$ Operator monthly salary, (L.E).

$0.9=$ Factor accounting for ratio of rated power and lubrications.

$144=$ The monthly average working hours.

The spreading cost per unit of production can be determined by the following equation:

Spreading $\operatorname{cost}(\mathrm{L} . \mathrm{E} / \mathrm{Mg})=$ Spreading cost $(\mathrm{L} . \mathrm{E} . /$ fed $) /$ Total yield $(\mathrm{Mg} / \mathrm{fed})$

\section{D-Model Description:}

For predicting some engineering parameters of the twin disc broadcasting machine used under this experiment, the Curve Fit program version 1.37 (2001) was used to determine the relations between (application rate, rotation frequency of spinner, blade angle and spinner angle) in preliminary experiment and (forward speed, application rate, coefficient of variance, effective field capacity, energy required, power requirements, fuel consumption, skewing (R,L), yield and cost) in field experiment using the polynomial equations $\left(2^{\text {nd }}\right.$ degree). Fixed and running two parameters on Curve Fit program will be prevented, since two simultaneous data collected causing stack faults. The investigated polynomial equations were tested regardless of some fixed parameters such as (soil type, machine used, tractor and cultivated yield).

\section{RESULTS AND DISCUSSION}

The discussion will cover the obtained results as follows:

\section{A-The preliminary experiment:}

The obtained results from the preliminary experiment optimizing some operating parameters affecting the performance of a twin disc 
broadcasting machine and the uniformity of fertilizer spread pattern such as; spinner speed, blade angle, spinner angle and gate opening areas, using a granular Ammonium Nitrate.

Table (5): Effect of some operating parameters on coefficient of variation, coefficient of uniformity and pattern skewing using gate opening area of $6 \mathrm{~cm}^{2}$ without overlapping*.

\begin{tabular}{|c|c|c|c|c|c|c|c|c|c|c|}
\hline \multirow{2}{*}{\begin{tabular}{|l} 
Uniformity \\
indicators \\
\end{tabular}} & \multicolumn{4}{|c|}{ Spinner speed, rad/s } & \multicolumn{3}{|c|}{ Blade angle, deg } & \multicolumn{3}{|c|}{ Spinner angle,deg } \\
\hline & $\omega_{1}=31.4$ & $\omega_{2}=41.86$ & $\omega_{3}=52.3$ & $\omega_{4}=62.8$ & $\theta_{1}=0$ & $\theta_{2}={ }^{+} 15$ & $\theta_{3}=-15$ & $\alpha_{1}=0$ & $\alpha_{2}=+10$ & $\alpha_{3}=+20$ \\
\hline C.V., \% & 88 & & 5050 & & 54.80 & & & 50.50 & & .90 \\
\hline CI $\%$ & & & & & 20 & & & & 0 & 10 \\
\hline \multirow{2}{*}{$\mathbf{S}_{\mathbf{R}} \% / \mathbf{S}_{\mathbf{L} \%}$} & 37 & 49.12 & 56.51 & 50.35 & 57.75 & 49.58 & 56.51 & 56.51 & 48.77 & 47.15 \\
\hline & & & 43.49 & 49.65 & 42.25 & 50.42 & 43.49 & 43.49 & 51.23 & 52.85 \\
\hline
\end{tabular}

Table (6): Effect of some operating parameters on coefficient of variation, coefficient of uniformity and pattern skewing using gate opening area of $12 \mathrm{~cm}^{2}$ without overlapping*

\begin{tabular}{|c|c|c|c|c|c|c|c|c|c|c|}
\hline \multirow{2}{*}{$\begin{array}{l}\text { Uniformity } \\
\text { indicators }\end{array}$} & \multicolumn{4}{|c|}{ Spinner speed, $\mathrm{rad} / \mathrm{s}$} & \multicolumn{3}{|c|}{ Blade angle, deg } & \multicolumn{3}{|c|}{ Spinner angle,deg } \\
\hline & $\omega_{1}=31.4$ & $\omega_{2}=41.86$ & $\omega_{3}=52.3$ & $\omega_{4}=62.8$ & $\theta_{1}=\mathbf{0}$ & $\theta_{2}=+15$ & $\theta_{3}=-15$ & $\alpha_{1}=0$ & $\alpha_{2}={ }^{+} \mathbf{1 0}$ & $\alpha_{3}={ }^{+} \mathbf{2 0}$ \\
\hline C.V., ,\% & 55.60 & 52.52 & 48.13 & 52.12 & 57.83 & 51.31 & 48.13 & 48.13 & 52.00 & 51.54 \\
\hline C.U., \% & 44.60 & 47.48 & 51.87 & 47.88 & 48.17 & 48.69 & 51.87 & 51.87 & 48.00 & 48.46 \\
\hline \multirow{2}{*}{$\mathbf{S}_{R} \% / \mathbf{S}_{L} \%$} & 48.70 & 50.63 & 50.48 & 47.74 & 49.36 & 48.56 & 50.48 & 50.48 & 49.35 & 46.73 \\
\hline & 51.30 & 49.37 & 49.52 & 52.26 & 50.64 & 51.44 & 49.52 & 49.52 & 50.65 & 53.27 \\
\hline
\end{tabular}

Table (7): Effect of some operating parameters on coefficient of variation, coefficient of uniformity and pattern skewing using gate opening area of $18 \mathrm{~cm}^{2}$ without overlapping*.

\begin{tabular}{|c|c|c|c|c|c|c|c|c|c|c|}
\hline \multirow{2}{*}{$\begin{array}{l}\text { Uniformity } \\
\text { indicators }\end{array}$} & \multicolumn{4}{|c|}{ Spinner speed, rad/s } & \multicolumn{3}{|c|}{ Blade angle, deg. } & \multicolumn{3}{|c|}{ Spinner angle ,deg } \\
\hline & $\omega_{1}=31.4$ & $\omega_{2}=41.86$ & $\omega_{3}=52.3$ & $\omega_{4}=62.8$ & $\theta_{1}=0$ & $\theta_{2}=+15$ & $\theta_{3}=-15$ & $\alpha_{1}=0$ & $\alpha_{2}={ }^{+} \mathbf{1 0}$ & $\alpha_{3}=+20$ \\
\hline C.V., \% & 49.50 & 47.76 & 43.20 & 45.24 & 48.08 & 49.77 & 43.20 & 43.20 & 49.00 & 47.20 \\
\hline C.U.,\% & 50.50 & 52.24 & 56. & 54.76 & 51.92 & 50.23 & 56.80 & 56.80 & 51.00 & 52.80 \\
\hline \multirow{3}{*}{$\mathbf{S}_{\mathbf{R}} \% / \mathbf{S}_{\mathbf{L}} \%$} & 48.85 & 49.14 & 50.02 & 48.69 & 55.49 & 46.55 & 50.10 & 50.10 & 48.85 & 47.70 \\
\hline & & & & & & & & & & \\
\hline & & 50.86 & 49.98 & 51.31 & 4.51 & & & & & \\
\hline
\end{tabular}


Table (8): Effect of some operating parameters on coefficient of variation, coefficient of uniformity and pattern skewing using gate opening area of $24 \mathrm{~cm}^{2}$ without overlapping*.

\begin{tabular}{|c|c|c|c|c|c|c|c|c|c|c|}
\hline \multirow{2}{*}{$\begin{array}{l}\text { Uniformity } \\
\text { indicators }\end{array}$} & \multicolumn{4}{|c|}{ Spinner speed, rad/s } & \multicolumn{3}{|c|}{ Blade angle, deg } & \multicolumn{3}{|c|}{ Spinner angle ,deg } \\
\hline & $\omega_{1}=31$. & $\omega_{2}=41.86$ & $\omega_{3}=52$. & $\omega_{4}=62.8$ & $\theta_{1}=0$ & $\theta_{2}={ }^{+} 15$ & $\theta_{3}=-15$ & $\alpha_{1}=0$ & $\alpha_{2}={ }^{+}+10$ & $\alpha_{3}={ }^{+} 20$ \\
\hline C.V. \% & 50.92 & 48.31 & 45.38 & 47.84 & 46.50 & 47.36 & 45.38 & 45.38 & 48.80 & 46.76 \\
\hline C. & 4 & & & 36 & 53.50 & 5 & 5 & 54.62 & 5 & 53.24 \\
\hline \multirow{3}{*}{$\mathbf{S}_{\mathbf{R}} \% / \mathbf{S}_{\mathbf{L}} \%$} & 49.53 & 46.22 & 49.48 & 47.12 & 49.60 & \begin{tabular}{|l|l|}
47.14 \\
\end{tabular} & \begin{tabular}{|l|l}
49.48 \\
\end{tabular} & 49.48 & $\begin{array}{ll}38.70 \\
\end{array}$ & 47.65 \\
\hline & & & & & & & & & & - \\
\hline & 50.47 & 53.78 & 50.52 & 52.88 & 50.40 & 52.86 & 50.52 & 50.52 & \begin{tabular}{l|l}
2 \\
\end{tabular} & 52.35 \\
\hline
\end{tabular}

* Preliminary experiments at ( Four C-shaped blade and spinner height of $50 \mathrm{~cm}$ )

\section{1- Effect of spinner speed on the uniformity of spread pattern:}

Tables $(5,6,7$ and8) showed that four different values of spinner speeds of $31.4,41.86,52.3$ and $62.8 \mathrm{rad} / \mathrm{s}$, corresponding to $(300,400,500$ and 600 $\mathrm{rpm})$ respectively were tested. The previous data indicated a clear decrease in the values of coefficient of variation (C.V) as the spinner speed was increased from 31.4 to $52.3 \mathrm{rad} / \mathrm{s}$, but begins increase by increasing the spinner speed up to $62.8 \mathrm{rad} / \mathrm{s}$. It was attributed to the shattering of granules at high speeds of spinner which lead to the segregation and bouncing the particles on the rotating spinner. The obtained results in Table (7) and Fig.(2) showed that the spinner speed of $52.3 \mathrm{rad} / \mathrm{s}$ gave the best value of coefficient of variation $(43.80 \%)$ and highest value of coefficient of uniformity (56.20\%) and coefficient of correlation $\left(\mathrm{R}^{2}=98.32\right)$ through gate opening area of $18 \mathrm{~cm}^{2}$ using $\mathrm{C}$ shape blade, blade angle of $\left({ }^{-} 15^{\circ}\right)$, spinner dip angle of zero degree, and spinner height of $50 \mathrm{~cm}$. It can be concluded that uniformity of pattern was highly affected by the spinner speed. The relation between spinner speed and application rate can be determined by using equations in Table (9). Hence, it's clear that the most suitable spinner speed was $52.3 \mathrm{rad} / \mathrm{s}$ to improve the uniformity of spread pattern.

\section{2- Effect of blade angle on the uniformity of spread pattern:}

Tables (5, 6, 7 and 8) illustrated that three values of blade angle were investigated of $0,{ }^{+} 15$ and -15 degrees, at a constant spinner speed of 52.3 $\mathrm{rad} / \mathrm{s}$, spinner angle of zero degree and spinner height of $50 \mathrm{~cm}$ through 
different gate opening areas without overlapping. The obtained results showed that there was unnoticeable variation in the values of $\mathrm{CV}$ by changing blade angle from zero to the forward angle $\left({ }^{+} 15^{\circ}\right)$, while the best value of $\mathrm{C} . \mathrm{V}$ of $43.80 \%$ and the highest values of coefficient of uniformity (C.U) and coefficient of correlation $\left(\mathrm{R}^{2}=92.95\right)$ were achieved at backward angle of $\left(-15^{\circ}\right)$. The relation between blade angle and application rate can be predicted by the equation in Table (9) with gate opening area of $18 \mathrm{~cm}^{2}$. It is obvious that the blade angle of $\left({ }^{-1} 15^{\circ}\right)$, gave an acceptable pattern.

\section{3- Effect of spinner angle on the uniformity of the spread pattern:}

Tables $(5,6,7$ and 8) demonstrated the effect of the spinner angle on the spread pattern characteristics. The obtained results indicated that there was apparent increase in the values of C.V occurred by increasing the spinner angle value from zero to ${ }^{+} 20$ degree. It may attributed to the changes occurred in the feed zone position of fertilizer on the rotating disc which lead to non-uniform pattern. As shown in Tables (7) and (9) spinner angle of zero degree gave the best value of C.V of (43.8\%), highest values of C.U $(56.8 \%)$, and coefficient of correlation $\left(\mathrm{R}^{2}=98.50\right)$ with little skewing in the pattern using a constant spinner speed of 52.3 $\mathrm{rad} / \mathrm{s}$, blade angle of $\left({ }^{-} 15^{\circ}\right)$, spinner height of $50 \mathrm{~cm}$ through opening gate area of $18 \mathrm{~cm}^{2}$. From previous data, it is evident that spread pattern uniformity was highly affected by the spinner angle as shown in Table (9) and Fig.(4).

\section{B-The field experiments:}

The obtained data from field experiments were submitted and evaluated in a correlation analysis using the coefficient of correlation $\left(\mathrm{R}^{2}\right)$ to predict and determine the relation between some engineering parameters affecting the performance of a twin disc fertilizer broadcaster such as; application, power and energy requirement, coefficient of variation, coefficient of uniformity and pattern skewing. The correlation analysis was calculated using the polynomial equation model. The effective overlap of the subsequent passes of the spreader in the field will be taken into consideration during fertilizing sugar beet. 


\section{1- Effect of forward speed on application rate:}

Fig. (5) illustrated the effect of forward speed on fertilizer application rate using the optimum gate opening area of $18 \mathrm{~cm}^{2}$ with effective swath width of $11 \mathrm{~m}$ and effective overlap of $42.83 \%$. It was noticed that the increase of forward speed from 1.5 to $8 \mathrm{~km} / \mathrm{h}$ decrease rapidly the application rate by $57.49 \%$, however, forward speed of $2.5 \mathrm{~km} / \mathrm{h}$ gave the optimum application for sugar beet. As shown in Fig. (5) the correlation between forward speed and application rate was highly significant $\{\mathrm{y}=-$ $\left.0.8929 x^{2}-9.4327 x+261.5 \quad\left(R^{2}=0.9578\right)\right\}$.

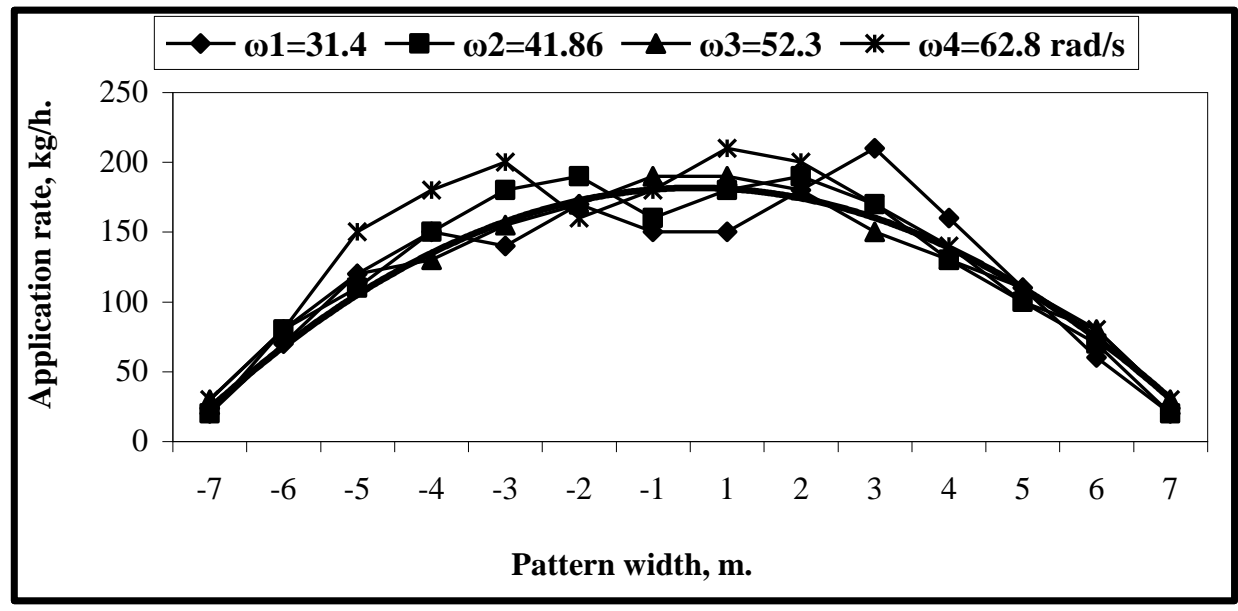

Fig (2): Effect of spinner speed on uniformity of fertilizer spread pattern at gate opening area of $18 \mathrm{~cm}^{2}$.

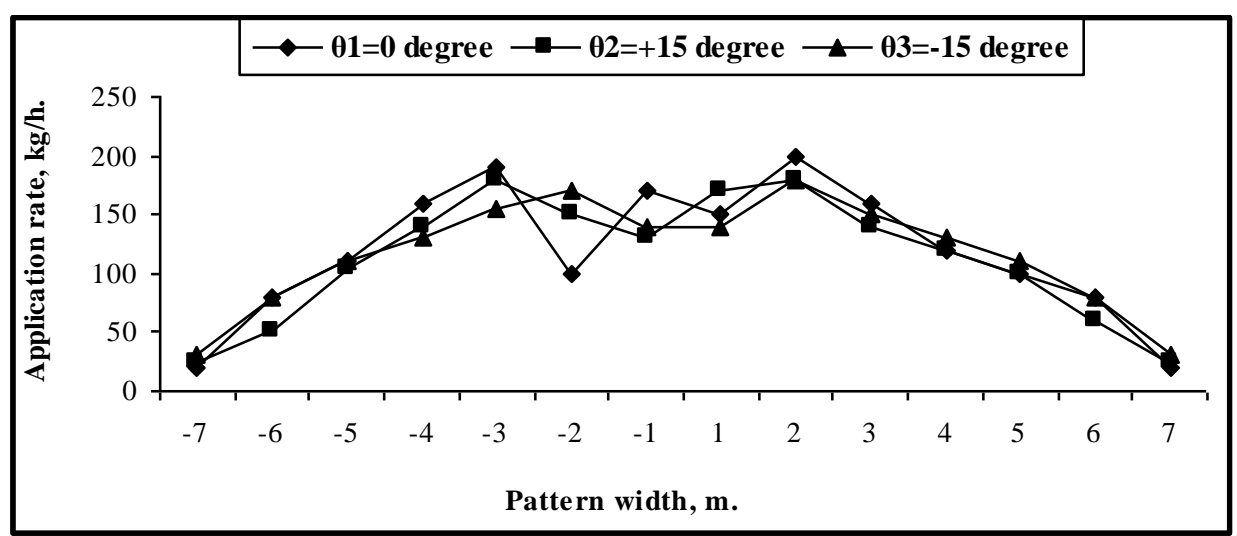

Fig (3): Effect of blade angle on uniformity of fertilizer spread pattern on gate opening area $18 \mathrm{~cm}^{2}$ without overlapping. 


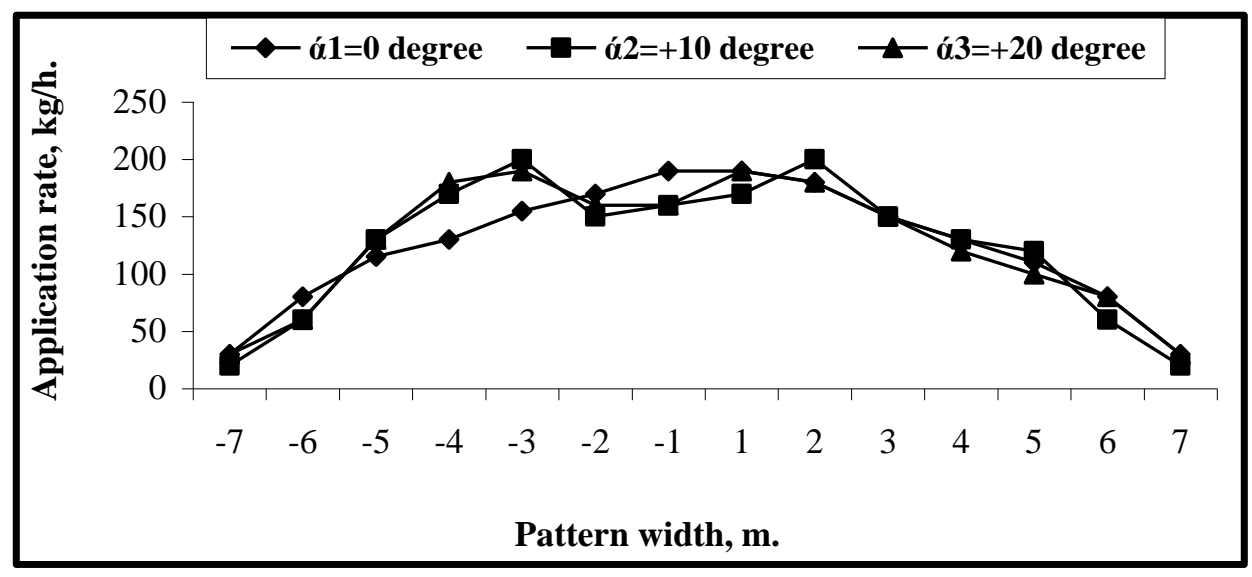

Fig (4): Effect of spinner angle on uniformity of fertilizer spread pattern on gate opening area of $18 \mathrm{~cm}^{2}$ without overlapping.

Table(9): Correlation equations between different operating parameters of the spreader and C.V. of spread pattern in the preliminary experiments*.

\begin{tabular}{|c|c|c|}
\hline Treatment & Equation & $\mathbf{R}^{\mathbf{2}}$ \\
\hline \multicolumn{3}{|c|}{ Spinner Speed } \\
\hline $\boldsymbol{\omega}_{1}$ & $\mathrm{Y}=-3.6607 \mathrm{x}^{2}+55.46 \mathrm{x}-28.407$ & 0.8680 \\
$\boldsymbol{\omega}_{2}$ & $\mathrm{Y}=-3.9148 \mathrm{x}^{2}+57.909 \mathrm{x}-25.495$ & 0.9661 \\
$\boldsymbol{\omega}_{3}$ & $\mathrm{Y}=-3.5543 \mathrm{x}^{2}+53.127 \mathrm{x}-16.126$ & 0.9832 \\
$\boldsymbol{\omega}_{4}$ & $\mathrm{Y}=-3.9354 \mathrm{x}^{2}+57.427 \mathrm{x}-8.956$ & 0.9225 \\
\hline \multicolumn{3}{|c|}{ Blade Angle } \\
\hline $\boldsymbol{\theta}_{1}$ & $\mathrm{Y}=-3.3723 \mathrm{x}^{2}+50.056 \mathrm{x}-12.363$ & 0.7905 \\
$\boldsymbol{\theta}_{2}$ & $\mathrm{Y}=-3.4341 \mathrm{x}^{2}+51.192 \mathrm{x}-22.473$ & 0.9070 \\
$\boldsymbol{\theta}_{3}$ & $\mathrm{Y}=-3.0185 \mathrm{x}^{2}+45.289 \mathrm{x}-4.0385$ & 0.9251 \\
\hline \multicolumn{3}{|c|}{ Spinner Angle } \\
\hline $\boldsymbol{\alpha}_{1}$ & $\mathrm{Y}=-3.5611 \mathrm{x}^{2}+53.329 \mathrm{x}-17.5$ & 0.9850 \\
$\boldsymbol{\alpha}_{2}$ & $\mathrm{Y}=-3.8324 \mathrm{x}^{2}+56.475 \mathrm{x}-21.429$ & 0.8895 \\
$\boldsymbol{\alpha}_{3}$ & $\mathrm{Y}=-3.6126 \mathrm{x}^{2}+52.915 \mathrm{x}-9.2308$ & 0.9020 \\
\hline
\end{tabular}

$*$ all equations in the range of the experiments conditions.

\section{2-Effect of forward speed on uniformity of fertilizer spread pattern:}

Figs. (5, 6 and 7) demonstrated the effect of forward speed on fertilizer spread pattern using the optimum operating parameters with effective swath width and overlap of $11 \mathrm{~m}$ and $42.83 \%$ respectively. It is noticed that a value of coefficient of variation (C.V) increase consequently as the 
forward speed was increased. The lowest value of (C.V) was observed at forward speed of $2.5 \mathrm{~km} / \mathrm{h}(9.75 \%)$ and little skewness of (50.40 / 44.60). The correlation between forward speed and coefficient of variation (C.V) was highly significant and can be predicted this relation with other forward speeds by the following equation $\left\{\mathrm{y}=0.0786 \mathrm{x}^{2}+0.7842 \mathrm{x}+\right.$ $7.273\left(\mathrm{R}^{2}=0.9996\right)$. While, the relationship between forward speed and pattern skewing was in right side $\left\{\mathrm{y}=-0.1421 \mathrm{x}^{2}+1.1102 \mathrm{x}+48.534\left(\mathrm{R}^{2}\right.\right.$ $=0.9961)\}$, and the left side was $\left\{\mathrm{y}=0.1421 \mathrm{x}^{2}-1.1102 \mathrm{x}+51.466\left(\mathrm{R}^{2}=\right.\right.$ 0.9961) \}as shown in Fig.(7). All equations in the range of the experiments conditions.

\section{3-Effect of forward speed on energy requirements:}

Fig. (9) showed that the increasing of forward speed led to decrease the energy requirement. The obtained data indicated that increasing forward speed from 2.5 to $8 \mathrm{~km} / \mathrm{h}$ decreased the energy requirements from 4.88 to $2.53 \mathrm{~kW} . \mathrm{h} / \mathrm{fed}$ by $51.84 \%$. The remarkable decrease in energy requirements values was attributed to the increase in machine effective field capacity. It is clear that energy requirements was affected by forward speed .The correlation between forward speed and energy requirements could be predicted by using this equation

$\left\{y=0.0714 x^{2}-1.1722 x+7.3499\left(R^{2}=0.9982\right)\right\}$. All equations in the range of the experiments conditions.

\section{4-Effect of forward speed on crop yield:}

Total yield of sugar beet was affected by forward speed of machine used. Fig. (11) showed that increasing forward speed from 2.5 to $8 \mathrm{~km} / \mathrm{h}$, decreases the total yield of sugar beet from 34.49 to $27.60 \mathrm{Mg} / \mathrm{fed}$ by $20 \%$. The decrease in total yield due to, that high forward speeds gave non recommended application rate. As shown in Fig. (11) the correlation expressed the relationship between forward speed and total yield, it is noticed that relationship was significant and can be predicated with other forward speeds by using the following equation $\left\{\mathrm{y}=-0.1321 \mathrm{x}^{2}+0.048 \mathrm{x}\right.$ $\left.+35.435\left(\mathrm{R}^{2}=0.948\right)\right\}$; while, the highest value of total yield of 34.49 $\mathrm{Mg} / \mathrm{fed}$ was observed at forward speed of $2.5 \mathrm{~km} / \mathrm{h}$ which gave the optimum application rate that met the plant growth requirements. The relationship between application rate and total yield could be predicted according to the following equation $\left\{y=0.5372 x^{2}-19.7 x+266.88\left(R^{2}=\right.\right.$ 
0.996)\} as shown in Fig.(10). All equations in the range of the experiments conditions.

\section{5-Effect of forward speed on spreading cost:}

Fig. (12) showed that the spreading cost decrease with increasing the forward speed. The obtained results revealed that spreading cost per unit of production decreased from 0.29 to 0.17 L.E./Mg by increasing the forward speed from 2.5 to $8 \mathrm{~km} / \mathrm{h}$. This decrease in spreading cost per unit of production was attributed to obvious decrease in spreading cost per unit area L.E./fed. The relationship between forward speed and spreading cost per unit of production can be predicted from this equation $\left\{y=0.0079 x^{2}-0.1063 x+0.5173\left(R^{2}=0.9992\right)\right\}$. While the correlation between total yield and spreading cost per unit of production can be expressed by the following equation $\left\{y=0.0058 x^{2}-0.347 x+5.3262\left(R^{2}\right.\right.$ $=0.7907)\}$ as shown in Fig. (13). All equations in the range of the experiments conditions.

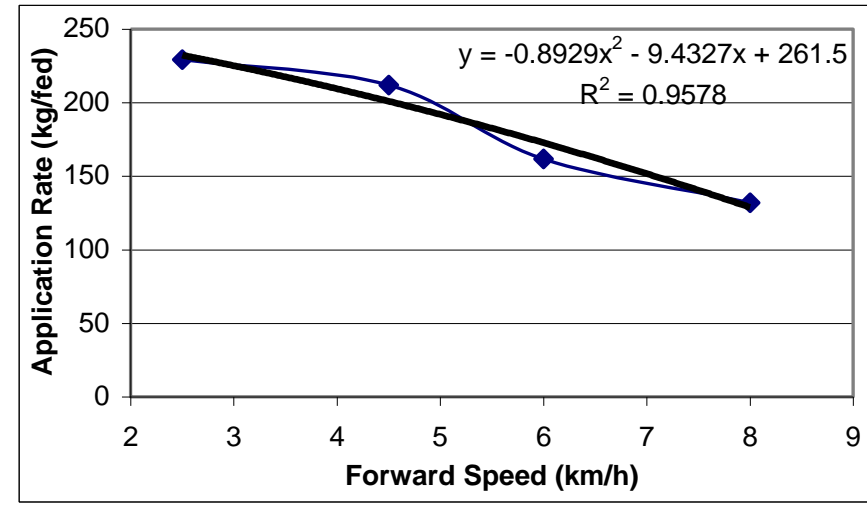

Fig.(5): Relationship between forward speed and application rate.

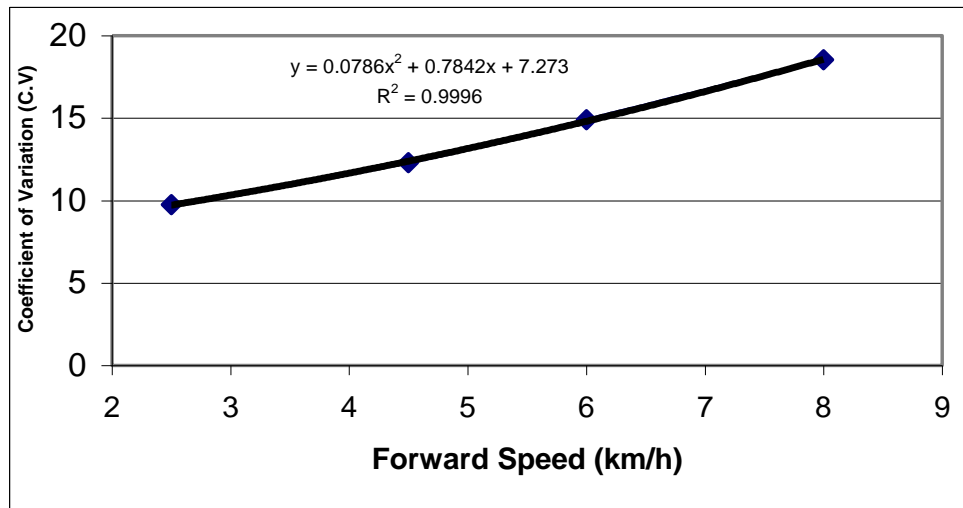

Fig.(6): Relationship between forward speed and coefficient of variation. 


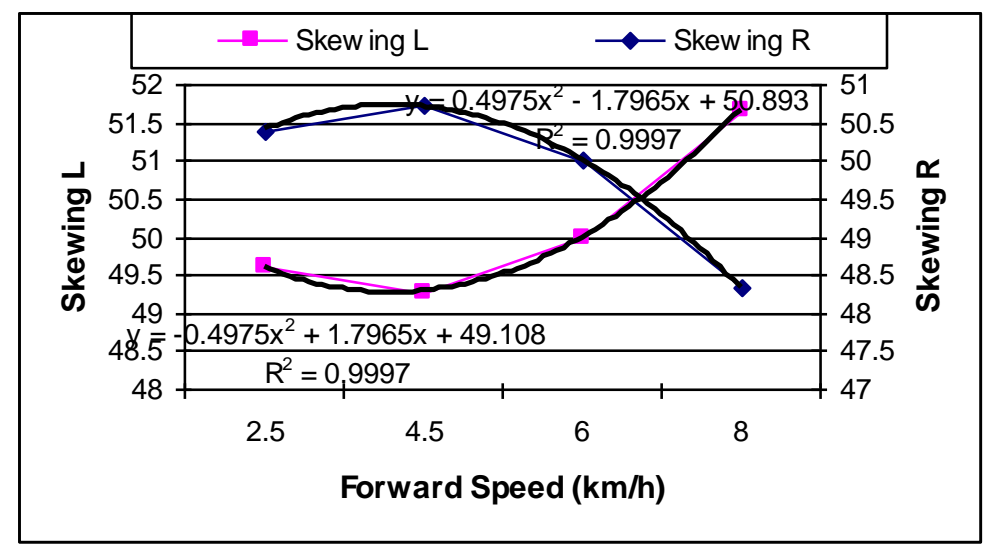

Fig.(7): Effect of forward speed on pattern skewing for right and left side.

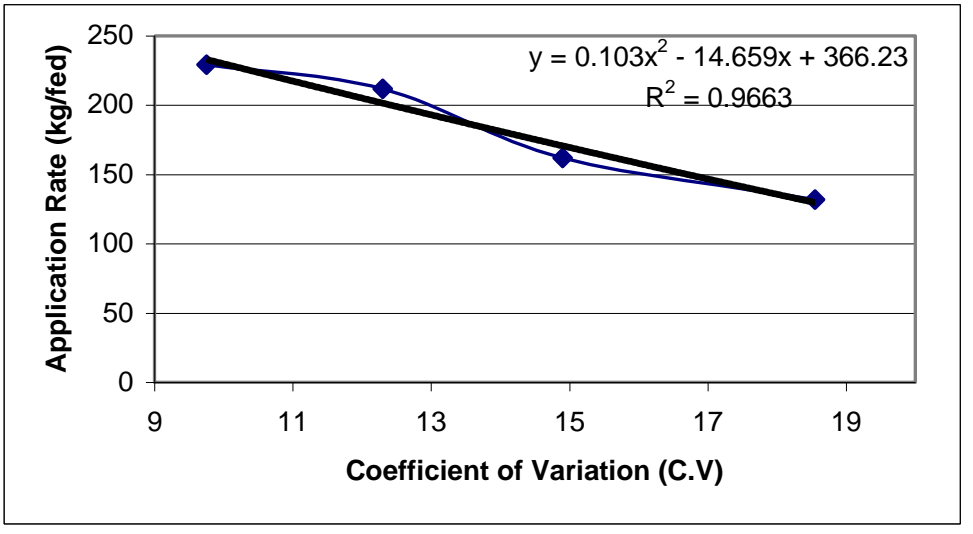

Fig.(8): Relationship between coefficient of variation and application rate.

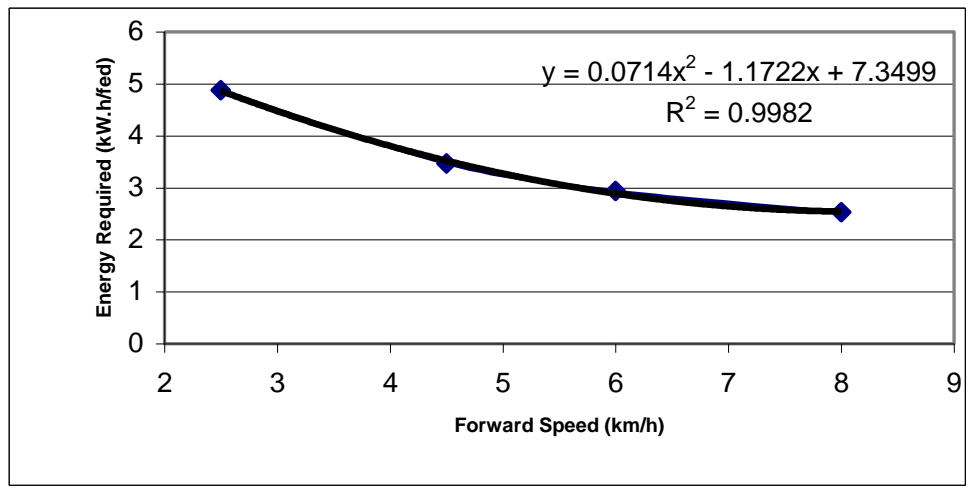

Fig.(9): Relationship between forward speed and energy required. 


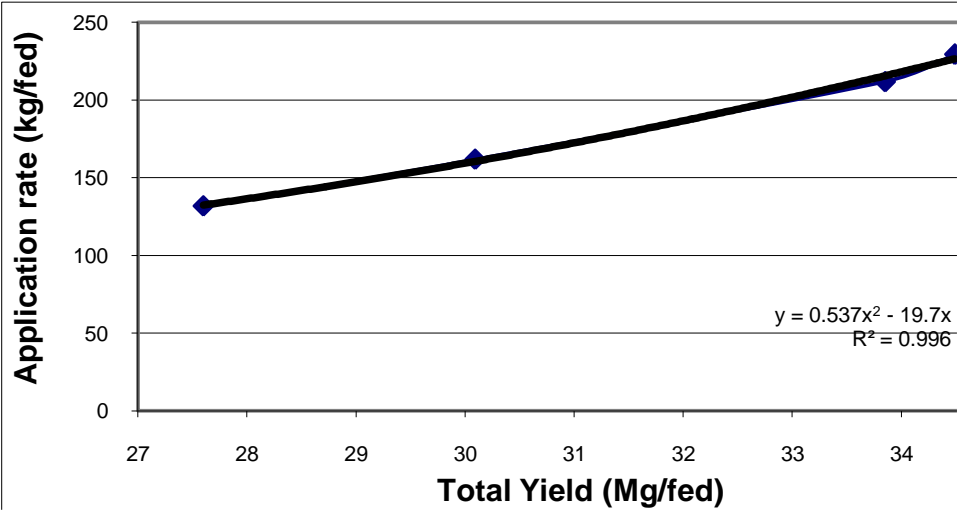

Fig.(10): Relationship between total yield and application rate.

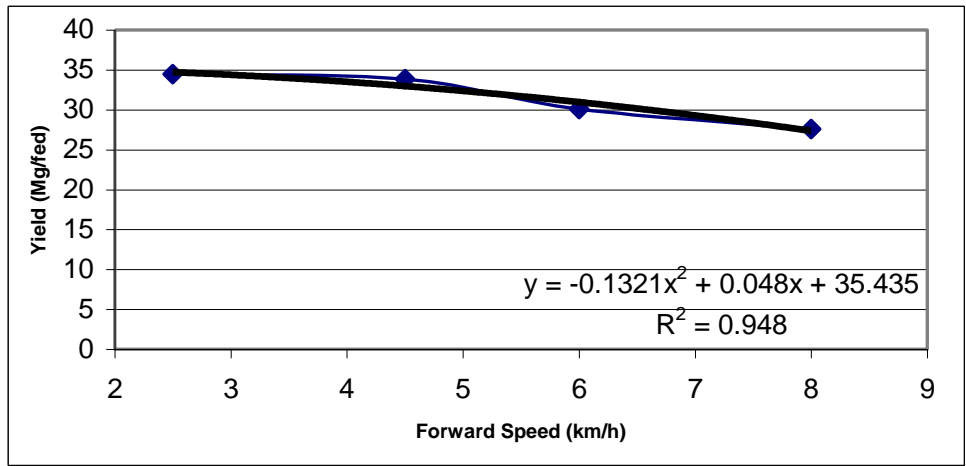

Fig.(11): Relationship between forward speed and total yield.

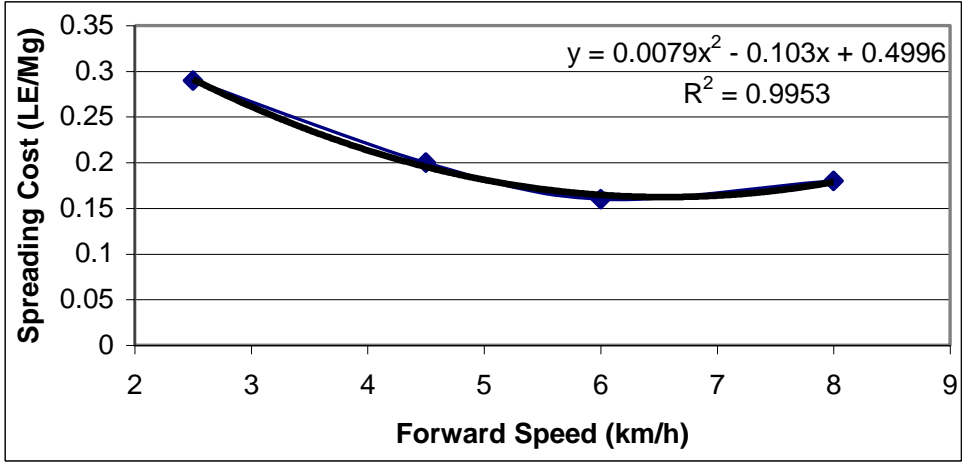

Fig.(12): Relationship between forward speed and spreading cost. 


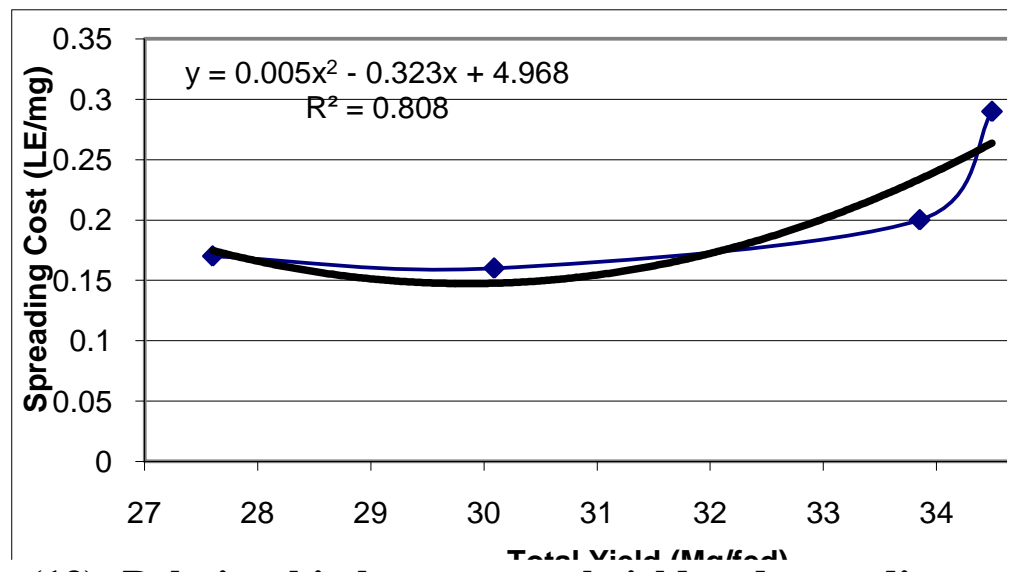

Fig.(13): Relationship between total yield and spreading cost.

\section{CONCLUSION}

From this investigation, the obtained results can be concluded as follows: 1- The obtained results from preliminary experiments of the twin-disc fertilizer spreader revealed that the lowest value of coefficient of variation (C.V) and the highest values of coefficient of uniformity and coefficient of correlation $\left(\mathrm{R}^{2}\right)$ were achieved under the following conditions: spinner speed of $52.3 \mathrm{rad} / \mathrm{s}(500 \mathrm{rpm})$, backward blade angle of $-15^{\circ}$, spinner angle of zero degree and gate opening of $18 \mathrm{~cm}^{2}$ using four C-shaped blades and spinner height of $50 \mathrm{~cm}$.

2- The best fit equations that obtained from field experiments results were proposed to express the relationship between forward speed of machine and the different operating parameters such as, application rate, pattern uniformity, energy requirement, total yield and spreading cost to predict the performance of the twin-disc spreader during fertilizing sugar beet in reclaimed area using granular Ammonium Nitrate.

3- The obtained data indicated that the high degree for both uniformity of spread pattern and correlation between the parameters affecting the performance of spreader can be achieved at overlap percentage of $43.80 \%$ (effective swath width $=11 \mathrm{~m}$ ) which gave an acceptable pyramidal pattern. 


\section{REFERENCES}

Ahmed S. F; M. A. Shaibon and A. A. Sayedahmed 1990. The field performance of an experimental spinner type fertilizer spreader. Misr J. Agric. Eng., 7 (4):348-358.

ASAE S 341.3, 2004. Procedure for measuring distribution uniformity and calibrating granular broadcasting spreader. ASAE standard book, 198-201.

Awady M. N. 1978. Engineering of tractor and agricultural machinery. Textbook, col. of agric., Ain Shams univ., 289 (in Arabic).

Curve Fit program version 1.37. 2001. Curve Expert-Curve, Fitting/Plotting Comprehensive curve fitting system for Windows (v1.37). Linear regression models, nonlinear regression models, interpolation, splines are supported.

Hassan M. A.; M. M. Morad; H. G. Gweifel and M. A. Tawfik 2005. Development of the manure fertilizing machine to improve its distribution pattern for spreading different types of fertilizers. Zagazig J. of Agric. Res., vol.32, No.(6):1913-1932.

Hofstee, J. W. 1993. Handling and spreading of fertilizer part 3, measurement of particle velocities and direction with Ultra Sonic transducers theory. J. of Agric. Eng. Res., 58 (1): 1-16.

Hunt R. D. 1983. Farm power and machinery management. 9th ed.,Cushing-Malloy Inc.,NY.

Kamel O. M.; M. E. Badawy and H. A. El Khateeb 2002. Evaluation performance of centrifugal fertilizer distribution from a twin disc spreader. Misr J. Agric. Eng., 19 (3):759-774.

Larry S. and V. A. Bandel 2002. Uniform lime and fertilizer spreading. Maryland cooperative extension. Col. of Agric., and natural resources, Univ., of Maryland. USA.

Morad M. M. 1990. Basic requirements in the design and development of the fertilizer broadcasting spreader. Misr J. Agric. Eng., 7 (4):402411 . 
Sayedahmed A. A. 1989. Design relationship for fertilizer broadcasting. M.Sc. thesis, Fac. of Agric., Alex Univ., Egypt.

Ziauddin A. M. and F. H. Khan 2002. An improved method of broadcasting seeds and fertilizers for small farm holders. ASAE paper No. 021058. Proceedings of ASAE annual international meeting CIGR xth world congress, Chicago, USA July 28-31,2002

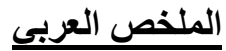 \\ أفضل طرق الإدارة المؤثرة على أداء موزع السماد ثنائي القرص في المناطق حديثة الاستصلاح}

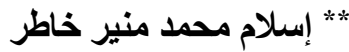

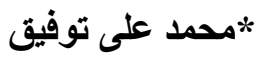

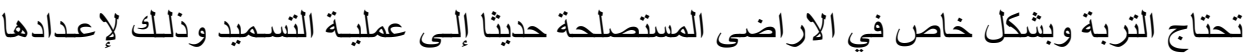

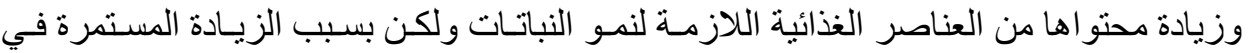

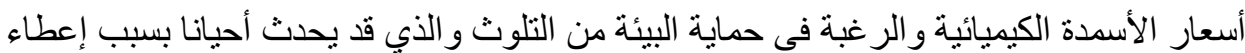

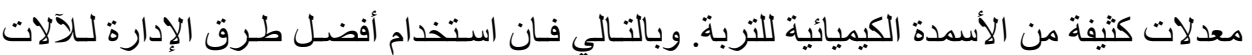

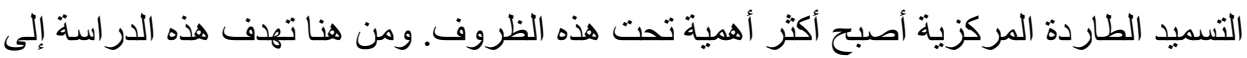

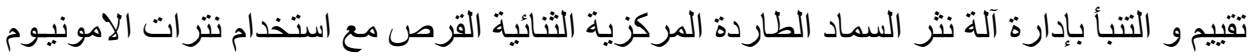

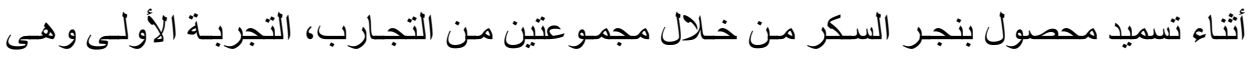

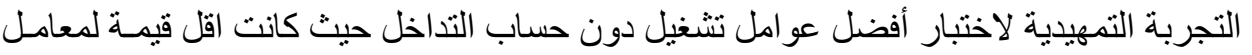

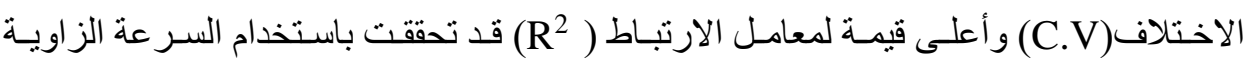

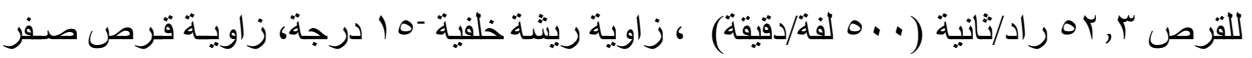

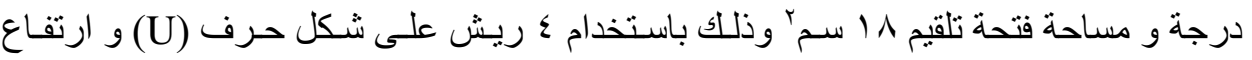

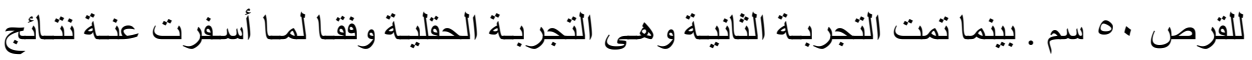

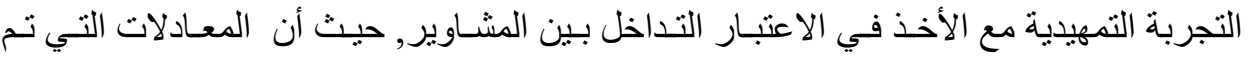

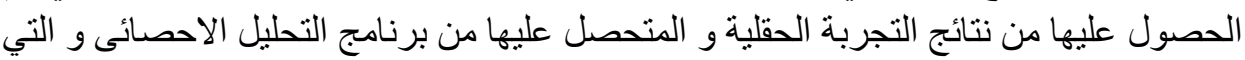

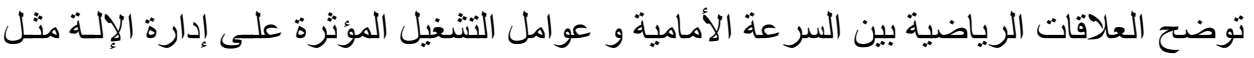

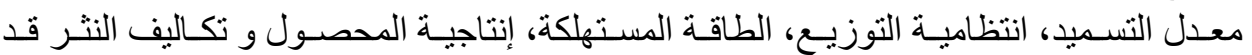

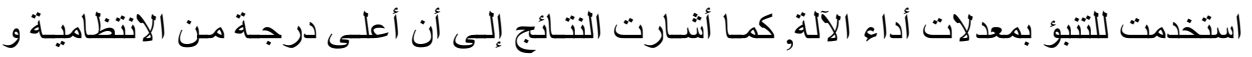

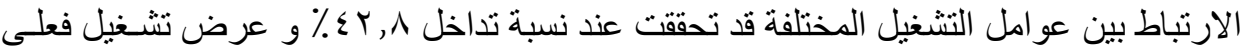
المو العطت شكل توزيع هرمي مقبول.

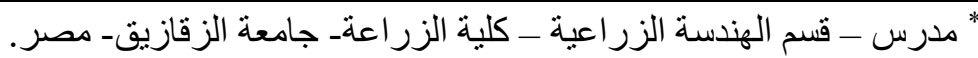

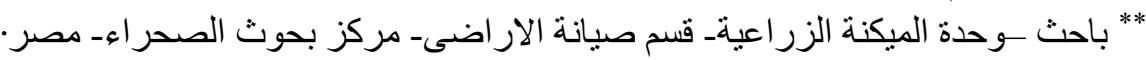

